\title{
From Barrio to “ßBoicoteo!”: The Emergence of Mexican American Activism in Davenport, 1917-1970
}

\author{
JANET WEAVER
}

ON NOVEMBER 18, 1969, Cesar Chavez addressed an enthusiastic gathering of some 500 local supporters at a grape boycott rally in Davenport, Iowa. He spoke of the "miserable wages, working and living conditions" of California grape pickers, and urged local activists to join him in a three-day fast over Thanksgiving to support the "hundreds of farm workers who cultivate the food for us, but who do not enjoy it themselves." ${ }^{11}$ His message resonated with the audience, which included a core group of Mexican American activists who had worked together to promote racial justice within their community for many years

1. Davenport-Bettendorf Times-Democrat, 11/9/1969, 11/18/1969, 11/19/1969.

The research for this article developed out of my work for the Mujeres Latinas Project of the Iowa Women's Archives at the University of Iowa Libraries. I acknowledge the many members of LULAC Council 10 who generously donated their time and expertise to make this research possible. In particular, I thank Salvador Lopez for his brilliant suggestion that we investigate the attic space above the old LULAC hall in Davenport, where, indeed, many treasures lay hidden. I appreciate the assistance of archivists Kathy Byers, St. Ambrose University Library Archives; and Karen O'Connor, Richardson-Sloane Special Collections Center, Davenport Public Library. I am grateful to the State Historical Society of Iowa for a research grant and to Sharon Lake, Karissa Haugeberg, Beatrice McKenzie, Roberta Till-Retz, and anonymous reviewers for reading earlier drafts of this essay and making helpful comments and suggestions. Thanks also to Shelton Stromquist and Omar Valerio-Jiménez, faculty members of the University of Iowa history department, and Kären Mason, curator of the Iowa Women's Archives, for critiquing late drafts of this essay.

THE ANNALS OF IOWA 68 (Summer 2009). (C) The State Historical Society of Iowa, 2009. 
and had been supporting the grape boycott actively for the past 11 months. They were, in effect, a generation of leaders forging a grassroots civil rights movement for whom the message of the Delano grape strike and boycott, delivered by its charismatic leader, sparked like tinder on a dry prairie.

The farm workers' struggle for justice stimulated what came to be known as the Chicano movement in the 1960s and 1970s. In this article, I trace the emerging activism of a small cadre of second-generation Mexican Americans in Davenport who led the local grape boycott campaign in the late 1960s. I explore how the grape boycott campaign, known as La Causa, provided a vehicle for broadening Mexican American activism in Davenport when local leaders concurrently took up the cause of Tejano migrant workers in Iowa, lending their support to the fiercely contested passage of the state's first migrant worker legislation. ${ }^{2}$

THE LEADERS of the Quad City grape boycott campaign were children of working-class Mexican nationals from the Central Plateau region of Mexico whose parents had settled in Iowa in the early decades of the twentieth century. ${ }^{3}$ During that pe-

2. The term Tejano refers to Mexican Americans from Texas, the majority of whom were U.S. citizens. Relatively little has been written about Mexican Americans in Iowa, due at least in part, until recently, to a lack of primary source documentation. For the history of Mexican Americans in the Midwest more generally, see Juan R. Garcia, Mexicans in the Midwest, 1900-1932 (Tucson, AZ, 1996); Jim Norris, North for the Harvest: Mexican Workers, Growers, and the Sugar Beet Industry (St. Paul, MN, 2009); Dionicio Nodín Valdés, Barrios Norteños: St. Paul and Midwestern Mexican Communities in the Twentieth Century (Austin, TX, 2000); idem, Al Norte: Agricultural Workers in the Great Lakes Region, 19171970 (Austin, TX, 1991); Zaragosa Vargas, Proletarians of the North: A History of Mexican Industrial Workers in Detroit and the Midwest, 1917-1933 (Berkeley, CA, 1993); David A. Badillo, "The Catholic Church and the Making of MexicanAmerican Parish Communities in the Midwest," in Mexican Americans and the Catholic Church, ed. Jay P. Dolan and Gilberto M. Hinojosa (Notre Dame, IN, 1994); and Richard Santillán, "Latino Politics in the Midwestern United States: 1915-1986," in Latinos and the Political System, ed. F. Chris Garcia (Notre Dame, IN, 1988).

3. George T. Edson, "Mexicans in the North Central States," 3, folder 38, box 13, Paul Taylor Collection, Bancroft Library, University of California Berkeley, Berkeley, CA (Bancroft microfilm reel 2414); Ernest Rodriguez, "Historical Synopsis of the Mexican Americans of the Quint-Cities," undated, "Impressions," Ernest Rodriguez Papers, Iowa Women's Archives (hereafter cited as IWA), University of Iowa Libraries, Iowa City. For an excellent analysis showing 
riod Mexican migration to the United States and the Midwest was fueled by the social and economic upheaval caused by the Mexican Revolution and by U.S. companies recruiting labor along the Mexican border. The first Mexicans to settle in Iowa worked on railroad section gangs, in foundries, and as migrant agricultural laborers in the sugar beet fields of northern Iowa. For these recent arrivals to the Midwest, employment was dictated by the season and by the availability of work and often involved a combination of industrial and agricultural jobs. ${ }^{4}$

The influx of Mexican immigrants into Iowa industries followed the acute labor shortage that developed during World War I. In the face of sharply declining numbers of European immigrants during the war, demand for Mexican labor surged in Iowa as it did in other parts of the country. Between 1900 and 1920, the estimated Mexican population in Iowa rose sharply from 29 to 2,560, with the largest increase occurring between 1910 and 1920, the decade that encompassed the Mexican Revolution and World War I. ${ }^{5}$ By 1927, more than 1,000 Mexicans lived in the Quad Cities area, equally divided between settlements on the Iowa side of the river - in Davenport, Bettendorf, and Nahant - and settlements on the Illinois side - in Rock Island, Moline, East Moline, and Silvis. Most worked for the Bettendorf Company and the Rock Island Railroad, with the

place of origin of Mexicans who settled in the Quad Cities, see Carmella L. Schaecher, "Boxcars, Colonias, and Heroes: A History of Mexicans in the Quad Cities, 1917-1945" (honors thesis, Stanford University, 2000), 32.

4. Vargas, Proletarians of the North, 24-29. For example, Esperanza Martínez, a sugar beet worker who settled with her husband, Cruz, near Manly, Iowa, in the 1920s, moved to Davenport after her husband and daughter died in the 1930s. She worked in a poultry factory to support her remaining children. Adella Martínez, interview with author, Davenport, 10/24/2006, IWA; Adella Martínez and Lupe and Julio Serrano, interview with author, Davenport, 10/10/2006, IWA.

5. U.S. Census Office, Census Reports, vol. 1, Twelfth Census of the United States Taken in the Year 1900: Population (Washington, DC, 1901), part 1, table 33 at 734; U.S. Department of Commerce, Bureau of the Census, Thirteenth Census of the United States Taken in the Year 1910, vol. 2, Population: 1910 (Washington, DC, 1913), table 5 at 613; U.S. Department of Commerce, Bureau of the Census, Fourteenth Census of the United States Taken in the Year 1920: State Compendium: Iowa (Washington, DC,1924), table 6 at 317. Census figures are likely to undercount the actual number of Mexicans living in Iowa because, as transient workers, they were often missed by census reporters. 
remainder intermittently employed in agriculture and other industries. ${ }^{6}$

The Mexican settlement that came to be known as Holy City grew up in close proximity to the massive Bettendorf Car Company - a major supplier for the national railroad industry with manufacturing shops stretching for nearly a full mile along the Mississippi River. In 1918 the first 150 Mexicans were recruited to work in the company's foundries. ${ }^{7}$ By 1925 , Holy City was a predominantly Mexican settlement; its residents were employed as pieceworkers and day laborers with earnings ranging from as little as $\$ 46$ to as much as $\$ 1,853$ annually. They faced frequent layoffs with few opportunities for alternative employment because most Davenport factories had "policies opposed to hiring Mexicans." 8

Ernest Rodriguez, who would become a leader in the local grape boycott campaign, was born in 1928 in Boxcar No. 8 in Holy City. His father, Norberto Rodriguez, had struck out for the United States in 1910, leaving behind his home in the state of Jalisco, Mexico. While working in the coal mines of south cen-

6. George T. Edson, "Mexicans at Davenport, IA and Moline, ILL.," 1, George T. Edson Field Reports: Iowa, 1927, folder 30, box 13, Paul Taylor Collection, Bancroft Library, University of California Berkeley, Berkeley, CA (Bancroft microfilm reel 2649:5, frames 457-70). The marshland area known as Nahant was the site of a railroad roundhouse on the outskirts of Davenport where Mexicans worked in the 1920s. Salvador Lopez, interview with author, Davenport, 5/21/2007, IWA; Mary Vasquez Olvera, interview with author, Davenport, 11/7/2006, IWA.

7. Edson, "Mexicans at Davenport and Moline," 1-4; Frederick I. Anderson, ed., Quad Cities: Joined by a River (Davenport, 1982), 137-40. In 1915 David Macias became the first Mexican to work in the Bettendorf shops. See "Manuel Macias, 1891-1954," Ernest Rodriguez Papers, IWA. When Edson referred to the Bettendorf Company as having a large "car" manufacturing plant at Bettendorf, he meant a railroad car manufacturing plant, not an automobile manufacturing plant as has been asserted in some accounts of early twentieth-century Mexican employment in the Quad Cities.

8. Edson, "Mexicans at Davenport and Moline," 4. It is reasonable to assume that the annual wage of $\$ 46$ recorded by Edson reflected short-term or seasonal employment. For descriptions of Holy City, see Juanita and Ernest Rodriguez, interview with Iskra Nuñez and author, Davenport, 8/6/2005, IWA; Estefanía Rodriguez, interview with Iskra Nuñez, Davenport, 8/11/2005, IWA; "Impressions," Ernest Rodriguez Papers; John Ryan, "A Not So Holy Shanty Town," in Ernest Rodriguez Papers; Roald D. Tweet, The Quad Cities: An American Mosaic (Rock Island, IL, 1996). 


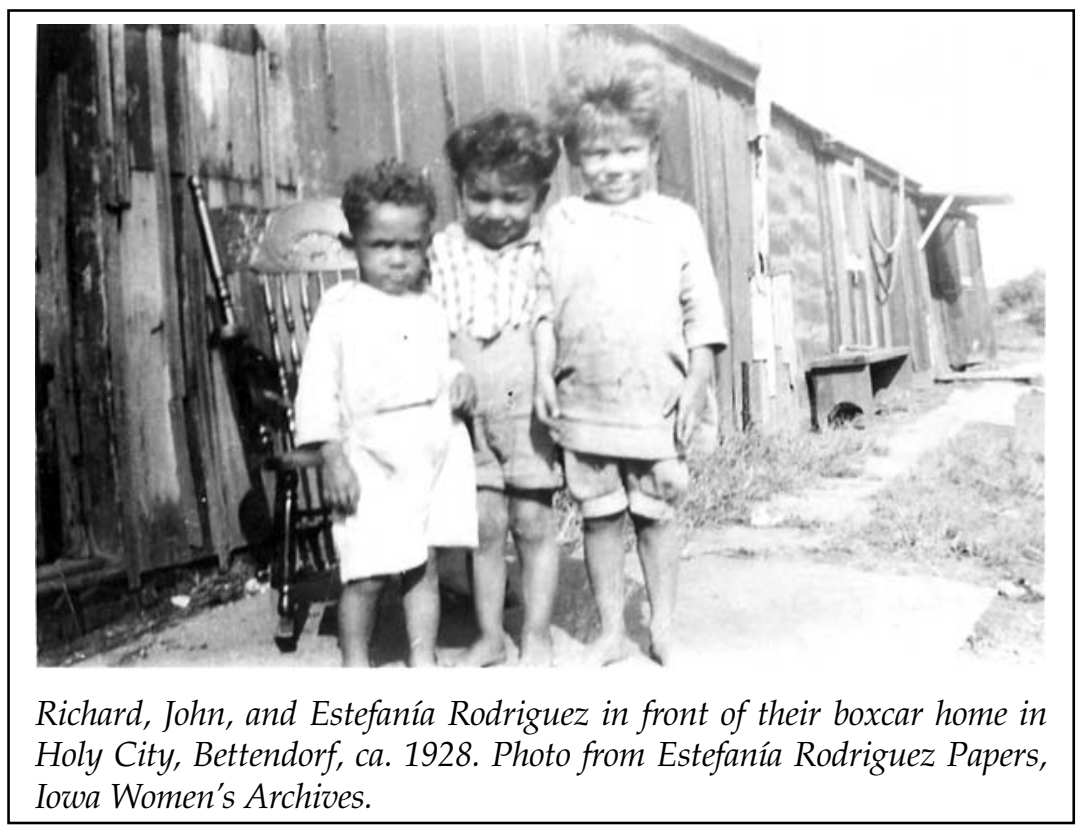

tral Iowa, he married an African American woman. In 1923 the family moved to Bettendorf, where Rodriguez was hired as a chipper in the Bettendorf foundry. His annual earnings were recorded at $\$ 1,195.57$ in 1925, roughly average for Mexican workers in the Midwest at that time.

With little outside interference, community life flourished in Holy City during the 1920s, rooted in the strong sense of ethnic traditions maintained by its residents. During the Great Depression, despite declining employment opportunities, many continued to live in the barrio's company housing, where rents were low or free. As Ernest Rodriguez recalled, the residents "all had

9. Biographical, family history, and speeches folders, Ernest Rodriguez Papers; Ernest Rodriguez interview, 8/6/2005; Edson, "Mexicans in the North Central States," 19 (reel 2414); Edson, "Mexicans living in Bettendorf, IA" 1, George T. Edson Field Reports: Iowa, 1927, folder 30, box 13, Paul Taylor Collection, Bancroft Library (Bancroft microfilm reel 2649:5, frame 471). In his list of employees of the Bettendorf Company in 1925, Edson recorded "A. Rodriguez" as a chipper in the foundry. Norberto Rodriguez was known as Albert Rodriguez by Anglos; because Edson's dates coincide with other written documents and oral histories, this is very likely Ernest Rodriguez's father. According to The Inflation Calculator at www.westegg.com/inflation/, Rodriguez's earnings of $\$ 1,196$ in 1925 would be roughly equivalent to $\$ 14,573$ in 2008. 
one thing in common, we were all poor and our Dads either worked in the Bettendorf Shops, the Zimmerman Foundry or on the WPA. Depending on how long work lasted all of us at one time or another were on what was known then as relief." ${ }^{10}$

Although Mexicans in the Quad Cities suffered extreme hardship during the Depression, they were not subject to the forced repatriation campaigns prevalent in some midwestern cities at that time. ${ }^{11}$ By 1932 the Bettendorf Company had closed its doors, and in the years that followed some chose to return to Mexico, but many remained, moving to other low-income areas in the Quad Cities, such as Cook's Point in southwest Davenport. ${ }^{12}$ The decision to stay fostered a historical memory of the barrios and provided generational continuity to the Mexican experience in Davenport that would be an important factor in determining future activism and support for the grape boycott. ${ }^{13}$

The future chair of the Quad City Grape Boycott Committee, John Terronez, was born in 1938 in the Cook's Point barrio that had been home to his mother since 1923. Mary Ramirez Terronez was just three years old in 1921 when her father, Dionisio Ramirez, left the family home in the state of San Luis Potosí, Mexico, to work for the Chicago, Rock Island \& Pacific Railroad in Davenport. ${ }^{14}$ The Cook's Point settlement that developed in the late 1910s was originally a shanty town for transient railroad and migrant workers who lived there during the winter months. By the 1920s, "the Point," as it was known, had become a permanent home to some of Davenport's poorest residents, many of whom were Mexican nationals.

In many ways typical of other Mexican settlements scattered throughout Iowa and the Midwest, Cook's Point lacked paved

10. Quote in "My Name is Ernest Rodriguez and I Am . ..," speeches folder, Ernest Rodriguez Papers; Ernest Rodriguez, "Impressions," ibid.; Ernest Rodriguez, "Rodriguez Family from Holy City, Bettendorf, Iowa," family history folder, ibid.; "Manuel Macias, 1891-1954," ibid.

11. Francisco E. Balderrama and Raymond Rodríguez, Decade of Betrayal: Mexican Repatriation in the 1930s (Albuquerque, NM, 1995), 168; Valdés, Barrios Norteños, 90-100; Schaecher, "Boxcars, Colonias, and Heroes," 85.

12. Anderson, Quad Cities: Joined by a River, 144-45; Tweet, The Quad Cities, 51.

13. Mario T. García, Mexican Americans: Leadership, Ideology and Identity, 19301960 (New Haven, CT, 1989); Santillán, “Latino Politics,” 104.

14. Biographical information, Mary Terronez Papers, IWA. 
streets, sidewalks, electricity, running water, and sanitary facilities. Situated on a two-acre, triangular piece of land along the Mississippi River that was prone to regular flooding, its housing ranged from sturdy frame homes to makeshift shacks, boathouses, and boxcars. A city dump was located nearby. In 1927 approximately 100 people lived at Cook's Point. Its population continued to expand until, by 1949, 270 residents lived in 56 homes on the site. ${ }^{15}$

During periods of layoff, Cook's Point residents looked to the sugar beet fields of northern Iowa and Minnesota to supplement their income. The journey north took two days, and the work, which involved the whole family, consisted of thinning in the spring, hoeing and weeding in the growing season, and topping the beets at harvest time. In 1926 more than 2,000 Mexican nationals worked in Iowa's sugar beet fields. During the Depression, such work was one of few employment options available to Iowa's Spanish-speaking residents. ${ }^{16}$

The childhood of Henry Vargas, who would later head the Huelga Committee for the local grape boycott campaign, was also defined by the barrios. Born in Davenport in 1929, his family moved to Cook's Point when he was 9 years old. His parents left Mexico in 1916 as a result of the economic upheaval caused by the Mexican Revolution and settled in Davenport, where his father worked for the Rock Island Railroad. The Vargas family lived in a small boxcar community behind the Crescent Macaroni factory until 1935, when the city removed the boxcars in an effort to improve inner-city living conditions. The family moved

\footnotetext{
15. Edson, "Mexicans at Davenport and Moline," 5-6; George William McDaniel, "Catholic Action in Davenport: St. Ambrose College and the League for Social Justice," Annals of Iowa 55 (1996), 260-62; "Cook's Point Economic Survey: Tabulation of Results," 1949 [a survey conducted by members of the Industrial and Human Relations Club at St. Ambrose College], Rev. William T. O'Connor Collection, St. Ambrose University Library Archives. For descriptions of Cook's Point, see oral history interviews with Maria Aguilera, 9/22/2005; Henry Vargas, 10/3/2006; Salvador Lopez, 5/21/2007; and Mary Vasquez Olvera, $11 / 7 / 2006$ (all conducted by the author in Davenport, all in IWA).

16. Edson, "Mexicans in the North Central States," 13, 17 (table 4: Contract Earnings of Mexicans in Sugar Beet Fields); Mary Terronez, interview with Kären Mason, Davenport, 12/30/2003, IWA; Mary Terronez and Phyllis Fillers, interview with author, Davenport, 11/6/2007, IWA; Florence Vallejo Terronez, interview with author, East Moline, Illinois, 11/6/2007; Valdés, Al Norté.
} 
to Cook's Point in 1938, attracted by the opportunity to have a large garden and raise their own vegetables, a longstanding tradition in their native state of Michoacán, Mexico. ${ }^{17}$

Hard times fell on the family when Henry's father was killed in a hit-and-run accident on New Year's Eve in 1941. After her three oldest sons were drafted into the military, Henry's mother found work in a nearby poultry processing factory. As the oldest son now living at home, Henry felt responsible for the family and decided to leave school. As he later explained, "I just couldn't see her coming home with her hands all bleeding from working in that. So I'd had it; I quit school." ${ }^{18}$

Like other Cook's Point residents, Henry Vargas and his siblings supplemented the family income by working in the onion fields of nearby Pleasant Valley, where onion growing was a major business. Each season, several hundred acres of rich bottomlands yielded between 350 and 500 boxcar loads of top quality onions. ${ }^{19}$ The workers were paid on a piecework basis. Over the years, Mary Terronez, Henry's neighbor at Cook's Point and John Terronez's mother, developed the practice of conducting negotiations with Pleasant Valley growers on behalf of the farm workers.

I used to drive a truck and before I went to work, I'd pick all the onion toppers up, take them to the fields, and I'd talk to [the growers], to different ones - "And how much are you going to pay us and what are you going to do for us when we get done?" And lots of them would go up two cents, because it was really cheap per bushel, "And when you get done we'll get pop and watermelons. How's that? That's good!" So I'd take my people over there, I negotiated for them. ${ }^{20}$

17. Henry Vargas interview, 10/3/2006.

18. Ibid.

19. Ibid; Adella Martínez and Lupe and Julio Serrano interview; Times-Democrat, 5/4/1969, 8/16/1970; Anderson, Quad Cities: Joined by a River, 145. See also Russell M. Rice, Fifty Years in the Onion Business (n.p., 1967); and Thomas L. Bell and Margaret M. Gripshover, "Agricultural Evolution and Devolution: Growth and Decline of the Onion-Growing Complex in Eastern Iowa" (paper presented at the annual meeting of the Association of American Geographers, Los Angeles, 2002).

20. Mary Terronez interview, 12/30/2003. 
Although informal, such negotiations helped farm workers maintain a minimal level of control over wages and working conditions.

As the children of the Mexican nationals who had settled in the Quad Cities during the 1920s came of age, the barrios gave way to urban development projects, and the cheap labor pool for onion topping dispersed. Although the descendants of those farm workers had moved out of the tightly knit barrio communities to nearby working-class neighborhoods, their collective memory and experience of stoop labor in Iowa's onion and sugar beet fields would shape and define their activism in the years ahead.

Equally significant to the molding of a collective generational experience out of which future activism would develop was the experience of Mexican Americans during the Second World War. In relation to their overall percentage of the population in the United States, Mexican Americans represented the largest minority group in the military during World War II and received more military honors than any other ethnic minority group. ${ }^{21}$ Women living in the barrios worked in defense and food production industries to support the war effort and provide for their families while husbands and sons served in the military. Within just three months during the war, one Cook's Point family lost two sons. ${ }^{22}$

The postwar experience of Quad City Mexican Americans further affected how they perceived their socioeconomic status in American society. Despite the significant sacrifices they had made during the war, there was little to suggest that their service ushered in a new era of opportunity for this ethnic group.

21. Marc Wilson, Hero Street, U.S.A.: The Story of Little Mexico's Fallen Soldiers (Norman, OK, 2009); Michelle Hall Kells, Hector P. García: Everyday Rhetoric and Mexican American Civil Rights (Carbondale, IL, 2006), 47; Dionicio Valdés, "The Mexican American Dream and World War II: A View from the Midwest," in Mexican Americans and World War II, ed. Maggie Rivas-Rodriguez (Austin, TX, 2005).

22. Luz Lopez Garcia, interview with author, Davenport, 7/9/2007, IWA; Mary Vasquez Olvera interview. Two of Olvera's brothers died during World War II: Albert Vasquez was a paratrooper who died in the Battle of the Bulge; three months later, his younger brother, Ralph Vasquez, was shot down by a sniper in Germany. Anderson, Quad Cities: Joined by a River, 190, notes that 10,000 Quad Cities residents served in the military during World War II, of whom 244 were killed in active duty. 
Discriminatory practices in housing, education, and employment continued, and soldiers returned home to find that they were denied membership in local Veterans of Foreign Wars chapters. However, although little had changed in their life circumstances, the war had fundamentally altered their willingness to accept the status quo. ${ }^{23}$ As Davenport World War II veteran Antonio Navarro explained,

We fought for the American ideals that our parents had taught us as children and believed our misfortune was merely a way of life. After the war we clearly realized that the deplorable conditions only existed because of racial discrimination. We were no longer afraid like our parents to confront the local officials regarding these terrible problems. Our battle for eliminating social discrimination was less frightening when compared to the horrors of the war we recently experienced. ${ }^{24}$

This perception was widely shared by working-class veterans of different racial and ethnic backgrounds, particularly minorities. In Texas, Mexican American GIs responded to persistent discrimination by forming the American GI Forum in $1948 .^{25}$

When the farm equipment industry expanded its base in the Quad Cities during the 1940s and 1950s, Davenport's Mexican Americans filled unskilled blue-collar positions at John Deere Plow and International Harvester. Joining recently organized industrial unions, they experienced firsthand the power of solidarity through the collective rank-and-file actions of militant grass-

23. Henry Vargas interview, 9/26/2006; Zaragosa Vargas, Labor Rights Are Civil Rights: Mexican American Workers in Twentieth-Century America (Princeton, NJ, 2005), 12-15; Wilson, Hero Street, U.S.A., 153.

24. Santillán, "Latino Politics," 105. Antonio Navarro - a native of Durango, Mexico - grew up in Holy City and was employed at Riverside Foundry in Bettendorf in 1941 when Pearl Harbor was attacked. He was drafted into the military, unaware that he was not a U.S. citizen until he was later sworn in along with several hundred other foreign-born GIs. See Iowa Public Television interview with Antonio Navarro conducted in 2007 at "World War II Veteran: Anthony Navarro," online transcript, Iowa Public Television, www.iptv.org/ video/detail.cfm/790/wwii_20071106_navarro.

25. The American GI Forum was founded in San Antonio, Texas, by Hector P. García to represent the rights of Mexican American veterans who suffered discrimination after World War II. Kells, Hector P. García, 46; Santillán, "Latino Politics,"105-6; Shelton Stromquist, Solidarity and Survival: An Oral History of Iowa Labor in the Twentieth Century (Iowa City, 1993), 151-52. 
roots organizations such as the CIO-affiliated Farm Equipment Workers (FE) and United Electrical Workers (UE). Many members of these leading left-wing unions were World War II veterans, apt to walk off the job to resolve shop floor grievances. Some were former mine workers who had cut their teeth in militant locals of the United Mine Workers of America in the mines of south central Iowa where John L. Lewis was born. ${ }^{26}$

The effectiveness of union solidarity impressed young workers such as Henry Vargas, who hired on as a laborer at John Deere Plow in 1948 and joined FE Local 150. Looking back on his early CIO union experience, Vargas noted that it was "almost like the grape boycott." His older brother, Jesse Vargas, a World War II veteran, played a central role in organizing workers at Riverside Foundry under the UAW and often discussed the benefits of trade unions with other Mexican Americans, encouraging them to become active in their locals. ${ }^{27}$

Despite positive experiences in some progressive $\mathrm{CIO}$ unions, the majority of Quad City Mexican Americans continued to work in low-wage, non-union factory jobs or as laborers in the building trades or in service sector jobs. A combination of limited educational opportunities and de facto discrimination effectively barred them from professional and clerical occupations. They were denied entrance to skilled apprenticeship programs in the AFL-affiliated building trades unions and overlooked for promotions in the railroad industry, a violation of the union contract that was condoned by Anglo officials of conservative railroad unions. Against this backdrop of persistent discrimination, together with the historical memory of field work, the message of

26. Stromquist, Solidarity and Survival, 168-69; John "Buckwheat" Serrano, interview with Merle Davis, Quad Cities, 3/3/1982, Iowa Labor History Oral Project (hereafter ILHOP), State Historical Society of Iowa (hereafter SHSI), Iowa City. For a detailed account of the history of FE and UE locals in the Quad Cities, see James Edward Foley, "Labor Union Jurisdictional Disputes in the Quad Cities' Farm Equipment Industry, 1949-1955" (M. A. thesis, University of Iowa, 1965). See also Rosemary Feurer, Radical Unionism in the Midwest, 1900-1950 (Urbana and Chicago, 2006); and the forthcoming article by Matt Mettler in the Annals of Iowa on the FE/UE Quad Cities locals. John L. Lewis was born in Lucas County, Iowa.

27. Henry Vargas interview, 9/26/2006; Henry Vargas, telephone interview with author, 5/14/2009; John Serrano interview; James Munro and Ray Jones, interview with Greg Zieren, Quad Cities, 7/9/1980, ILHOP. 
the grape boycott would take hold, igniting a flicker of hope for the possibility of change using old-line CIO union tactics. ${ }^{28}$

More than any other single event in Davenport during the postwar years, the forced closing of Cook's Point in 1952 reflected the extent to which living conditions for the city's Spanishspeaking population had remained unaltered. Residents were given just six months to evacuate the barrio. Their efforts to find affordable housing were constricted by high rents and the discriminatory practices of landlords and realtors. As events coalesced around this housing crisis, the ensuing struggle represented, perhaps ironically, an axis of change for a handful of barrio residents. ${ }^{29}$

The significance of the barrio's closing lay in the way it connected Mexican Americans with community civil rights and labor activists. That activism was substantially supported by a small group of progressive priests working out of the educational hub of the Roman Catholic Diocese of Davenport at St. Ambrose College. By the mid-1940s, the ideals of the papal encyclicals, which stressed that lay Catholics and clergy should work together to promote social justice, had become an integral part of the teaching at St. Ambrose, where issues of race and labor were emphasized in classes taught by activist priests. "In good Jocist fashion they urged their students to get involved, study a situation and to take action." In 1948, when 88 percent of the 1,256 students at St. Ambrose were veterans enrolled under the GI Bill, the teaching of an activist faculty met with a particularly responsive student body. ${ }^{30}$

28. Henry Vargas interviews; Salvador Lopez interview; Mary Terronez interview, 10/10/2006. Mexican American railroad employees, such as Salvador Lopez, often worked outside of their classification, in violation of the union contract, which union officials condoned by overlooking.

29. For an account of the history of the League for Social Justice and its involvement in the closing of Cook's Point, see McDaniel, "Catholic Action in Davenport," 239-72. The League for Social Justice was an interdenominational and interracial organization founded in Davenport in 1950 by Michael Lawrence to promote racial equality. Some members of the league were World War II veterans; others, such as Lawrence, were labor activists.

30. Ibid., quote at 140, from Michael Lawrence interview with George McDaniel, 7/23/1993. See also George William McDaniel, A Great and Lasting Beginning: The First 125 Years of St. Ambrose University (Davenport, 2006), 140-42. Key activists on the faculty at St. Ambrose College included Fr. William T. 
The philosophy of Father Bill O'Connor and other likeminded St. Ambrose faculty provided a parallel experience in Davenport to the early experience of Cesar Chavez in community organizing in Delano, California. In 1949 St. Ambrose students conducted a survey of Cook's Point under the guidance of the most outspoken member of the college faculty, Father Bill O'Connor, known as the "labor priest." As one student observed, "no matter what the course syllabus said, the course content was the social encyclicals as they applied to labor. . . O'Connor was ringing our ears for Rerum Novarum." The Cook's Point survey revealed that Davenport's Mexican Americans were subject to de facto discrimination similar to what African Americans experienced with regard to housing, employment and - to a lesser extent - public accommodations. ${ }^{31}$

In 1952 Cook's Point residents became acquainted with African American Catholic activists Charles and Ann Toney, who lived in Davenport's black neighborhood. The Toneys were good friends with Father Bill O'Connor and were leaders of the Davenport NAACP and members of the League for Social Justice. Seven years earlier they had won a landmark suit in Iowa district court against a Davenport resident who refused to serve them at a local ice cream parlor. ${ }^{32}$ Charles Toney was a welder

O'Connor, his brother, Fr. Ed O'Connor, Fr. Charles Francis Griffith, and Fr. Urban "Penny" Ruhl. The Jocist movement originated in Belgium in the 1910s, out of which emerged the "Observe-Judge-Act" formula for Catholic Action: observe a situation, judge whether or not it fits the teachings of Jesus, and take action to change it. It came to the United States in 1938, when it became associated with Chicago priest and labor activist Reynold Hillenbrand. See Jeffrey M. Burns, Disturbing the Peace: A History of the Christian Family Movement, 19491974 (Notre Dame, IN, 1999). This approach was taken up in Davenport by Rev. William T. O'Connor, a leading labor and civil rights activist in the Quad Cities from the 1940s to 1980s.

31. McDaniel, A Great and Lasting Beginning, quote at 142; Mario T. García, The Gospel of César Chávez: My Faith in Action (Lanham, MD, 2007), 8; Anderson, Quad Cities: Joined by a River, 188; "Racial Injustice in Davenport," Labor 26 (1963), 8-17, in O'Connor Collection, St. Ambrose University Library Archives; Rev. Marvin Mottet, interview with George McDaniel, Rev. George W. McDaniel Collection, St. Ambrose University Library Archives. Issued by Pope Leo XIII in 1891, the encyclical Rerum Novarum (On the Conditions of Labor) stressed the need to respect industrial workers and recognize their dignity.

32. George William McDaniel, "Trying Iowa's Civil Rights Act in Davenport: The Case of Charles and Ann Toney," Annals of Iowa 60 (2001), 231-43. 
and union member at John Deere Plow — where Henry Vargas was also employed - and had attended St. Ambrose College for one year. Cook's Point residents first met Ann Toney when she went door-to-door in Cook's Point conducting a survey of the barrio for the League for Social Justice. Over the ensuing months, the Ramirez, Terronez, and other Cook's Point families developed a lasting friendship with the Toneys. ${ }^{33}$

John Terronez was 13 years old in January 1952 when the Davenport City Council decided to clear the Cook's Point site in order to make way for industrial development. His mother, Mary Terronez, worked with the League for Social Justice to help residents of "the Point" find alternative housing. The harsh reality of growing up poor in the barrios had motivated her to hone skills in intercommunity relations. Feisty, outspoken and - by her grandmother's accounting - just plain "ornery," Mary communicated easily with a cross-section of employers, police, teachers, doctors and social service agencies. In her opinion, poverty rather than race was the defining feature of the barrio, and she helped individuals of different racial and ethnic backgrounds deal with the issues of poverty. As Mary Terronez would later assert, her son John was a lot like her. ${ }^{34}$

The closing of the barrio was perhaps as significant to those who provided assistance as it was to those who received it. A longstanding friendship developed between Father Bill O'Connor and the Terronez and Vargas families, who also became acquainted with Marvin Mottet, the then 18-year-old St. Ambrose College student who would later become a priest and strong proponent of civil rights in Davenport. ${ }^{35}$ The barrio's closing

33. Ibid.; Carmella and Perry Ramirez, interview with author, Davenport, 8/22/2008, IWA; Ann Toney, interview with author, Coal Valley, Illinois, 5/22/2008. Charles and Ann Toney became godparents to Perry and Carmella Ramirez's son shortly after Cook's Point was closed down.

34. McDaniel, "Catholic Action in Davenport"; biographical information, Mary Terronez Papers; Mary Terronez and Phyllis Fillers, interviews with author, Davenport, 11/6/2007 and 6/18/2009, in author's possession.

35. McDaniel, "Catholic Action in Davenport"; Henry Vargas interview, 9/26/ 2006; Rev. Marvin Mottet, interview with author, Davenport, 12/19/2006, IWA. After being ordained, Father Mottet became a key figure in civil rights in Davenport and, in January 1969, was appointed director of the Diocese of Davenport's newly created Department of Social Action. 
made a deep impression on Mottet, who quite literally assisted in moving Cook's Point homes, including Mary Terronez's, to a new area on old Highway 22 in southwest Davenport where her family had purchased land. Looking back on the Saturday mornings when he would jump in the St. Ambrose truck and go out to the site, he noted, "We dug basements and holes for cesspools and we even built a road in off the highway to move the houses in. So it was great. . . We had both the theory and the practice." ${ }^{36}$

The closing of Cook's Point represented a defining moment in the lives of a handful of Davenport Mexican Americans who determined to work for change. By providing an example of a coalition of activists and organizations working together, it accentuated the lack of their own organizations through which to advocate their needs. As Henry Vargas explained, "We seen what the NAACP could do . . . and we struggled to find an organization, a national organization, that would represent us." ${ }^{37}$

IN THE YEARS after the closing of Cook's Point, Davenport's Mexican Americans mobilized on three fronts: through organized labor, politics, and civil rights organizations. Local unions proved a practical training ground in the principles of labor solidarity, grassroots collective action, and participation in local politics. When the first Mexican American organizations formed in Davenport in the late 1950s, their blue-collar leaders intended to use them as a base from which to work for change. During the decade that preceded their entry into the Chicano movement, Mexican American leaders in Davenport maintained strong ties with activists in the Catholic church, and the experience they gleaned in community organizing enabled their effective future support for Cesar Chavez, the grape boycott, and the farm worker movement. ${ }^{38}$

36. Rev. Marvin Mottet, interview with author.

37. Henry Vargas interview, 9/26/2006.

38. Jeffrey M. Burns, "Establishing the Mexican Catholic Community in California: A Story of Neglect?" in Mexican Americans and the Catholic Church. In California in the late 1940s the Community Service Organization had a profound influence on Cesar Chavez (Burns, 204-6). Progressive priests in the Davenport Diocese provided a parallel experience for activists in the Quad Cities. 
During the 1950s, union involvement nurtured political activism among Quad City Mexican Americans. As John Terronez's uncle, Perry Ramirez, explained, "Most of the guys that got indoctrinated in the union went out into the community and became activists." Jesse Vargas was highly respected in the local labor movement and coordinated a successful UAW organizing drive at Riverside Foundry, where working conditions were notoriously bad. An Anglo fellow union member described Vargas as "the kind of guy who felt that people were getting cheated, and we needed help. And ... the only way we were going to get help was with the union." As a leader in the local labor movement, Vargas encouraged other Mexican Americans to become more active in local politics. As a result, by 1959 the leadership of the Scott County Young Democrats was decidedly Mexican American, with Jesse Vargas as president, Henry Vargas as chair of the membership committee, John Bribriesco as treasurer, and Ernest Rodriguez as publicity chair. ${ }^{39}$

The formation of local chapters of two Mexican American organizations in the late 1950s heralded the entry of their members into politics and civil rights. Davenport chapters of the American GIForum and the League of United Latin American Citizens (LULAC) followed the national organizations by emphasizing the importance of education and developing scholarship programs to provide opportunities for Mexican American students to pursue a college education. Both stressed participation in politics as a means to achieve social and economic parity, and members of both were active in the Democratic Party, forming and leading "Viva Kennedy" clubs during the 1960 presidential campaign. ${ }^{40}$

39. Perry Ramirez, telephone interview with author, Davenport, 5/20/2008; James Munro and Ray Jones, interview with Greg Zieren, Quad Cities, 7/9/ 1980, ILHOP; John Serrano, interview with Merle Davis, Quad Cities, 3/3/1982, ILHOP; Democratic Spotlight [Scott County Young Democrats newsletter], November 1959, Ernest Rodriguez Papers.

40. Augustine Olvera formed the first Iowa chapter of the American GI Forum in Davenport in 1958. "Viva Kennedy" clubs sprang up throughout the Southwest and the Midwest during the 1960 presidential campaign. Santillán, "Latino Politics," 106-8. The national LULAC organization originated in Texas in 1929 and expanded into the Midwest during the 1950s, when councils were organized in Illinois, Indiana, Iowa, Minnesota, and Wisconsin. Four other Iowa LULAC councils were chartered from 1956 to 1958: Fort Madison (No. 304), 


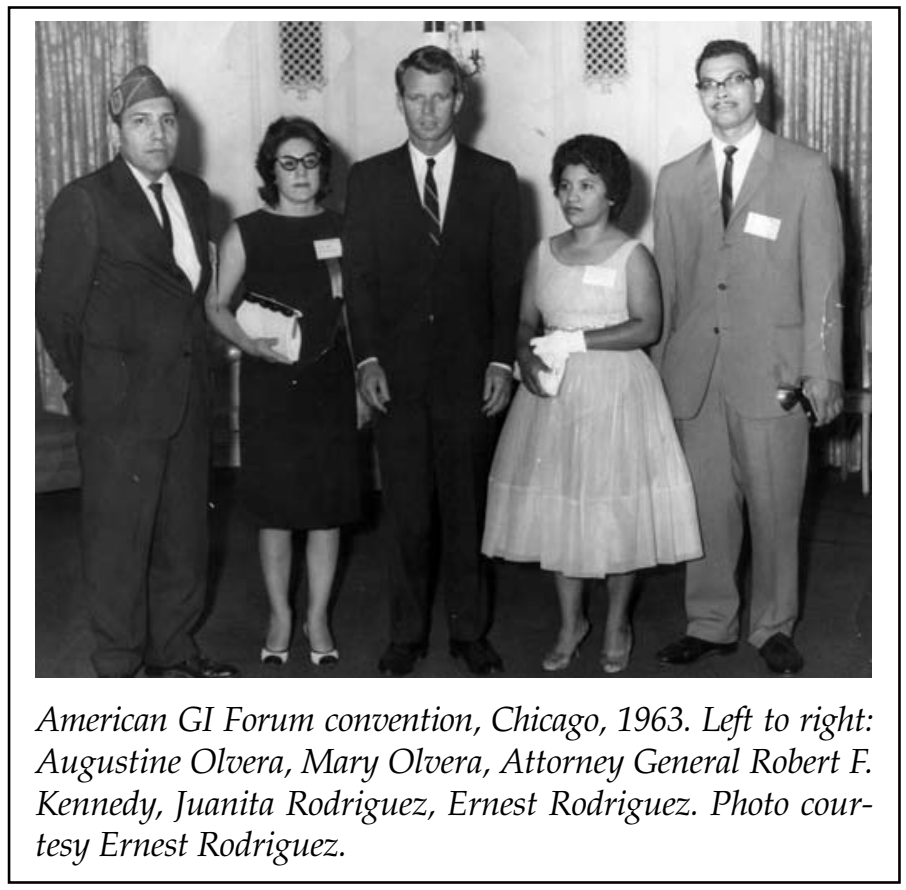

Through such organizations, members gained experience that would prove invaluable in furthering the interests of Mexican Americans locally and throughout the state. John Terronez, who was state director of Iowa LULAC at the time of the grape boycott, would later attribute his leadership skills to his involvement in LULAC, which, he explained, "taught me how to be part of the community and how to run an organization.." ${ }^{41}$

From its inception, LULAC Council 10 focused on achieving political power and quickly established its reputation as "Iowa's most active council." ${ }^{\prime 2}$ On April 15, 1959, just two months after its formation, Council 10 made front-page headlines when a delegation charged the Davenport City Council with discrimination in its decision to irrevocably suspend the Class B beer

Des Moines (No. 306), West Des Moines (No. 308), and Mason City (No. 314). LULAC Council 10 was chartered on February 16, 1959. Jesse Mosqueda and Felix Sanchez, "Iowa LULAC History, 1957-1972," LULAC 10 Records, IWA.

41. Quad City Times, 8/5/1979.

42. Mosqueda and Sanchez, "Iowa LULAC History." 
license of the Alibi tavern, the only Mexican-owned tavern in Davenport. The spokesperson for the group was Jesse Vargas, president of UAW Local 377. Accompanied by his brother Henry Vargas, Ernest Rodriguez, and John Bribriesco, Jesse Vargas argued that the council's decision was "too severe" and that the police investigation had been discriminatory, concluding, "This seems to be a case of whites versus Mexicans rather than one American citizen against another." ${ }^{\prime 3}$

The protest at city hall was the first indication of the activism that would become the hallmark of LULAC Council 10. One factor that contributed to the militant character of the Davenport council and differentiated it from LULAC councils in other parts of the country was the working-class basis of its membership. The founders and leaders of LULAC Council 10 were blue-collar workers who came out of the unionized factories, foundries, and railroads of the Quad Cities area. By contrast, LULAC councils in the Southwest that had organized more than 20 years earlier were typically led by an older, middle-class and professional generation that younger and more militant Chicanos criticized as being "Tío taco" - the Mexican equivalent of Uncle Tom. In Davenport, the founders and leaders of the council were members of this younger generation of Chicano activists who had not yet assimilated into the middle class as was typical of LULAC leadership in the Southwest. ${ }^{44}$

Another factor contributing to Council 10's activism was its proximity to and longstanding relationship with progressive faculty and students at St. Ambrose College. The League for Social Justice and its successor, the Catholic Interracial Council (CIC),

43. Morning Democrat, 4/7/1959, 4/15/1959; Daily Times, 4/7/1959, 4/15/1959; Times-Democrat, 4/11/1959; Davenport City Council Minutes, 4/15/1959, Richardson-Sloane Special Collections Center, Davenport Public Library.

44. Craig A. Kaplowitz, LULAC, Mexican Americans and National Policy (College Station, TX, 2005), 4-5. For an analysis of how the national LULAC developed from a civil rights organization to an elite-dominated organization, see Benjamin Márquez, LULAC: The Evolution of a Mexican American Political Organization (Austin, TX, 1993). It is interesting to note the contrast between the experience of LULAC Council 10 and that of Mexican American organizations in other parts of the Midwest. For example, the Milwaukee, Wisconsin, LULAC council established in 1957 had collapsed by 1963. "In the late 1950s and early 1960s there was a major breakdown of Mexican organizations in St. Paul, Minnesota," and the American GI Forum "just died." Valdés, Barrios Norteños, 172. 
were nurtured by progressive priests who promoted grassroots community action. The strong tradition of local activism, combined with the influence of progressive unionism, help explain why Chavez's message took hold in Davenport in the late 1960s in a way that it did not elsewhere in Iowa. ${ }^{45}$

In 1962 Henry Vargas served on the executive board of the Davenport $\mathrm{CIC}$, which coordinated an interracial home visit program and an annual brotherhood mass and lobbied state and local governments to pass and enforce fair housing and employment legislation. The Davenport CIC joined forces with local civil rights groups to organize a rally that took place on the Davenport levee five days before the national March on Washington. John Howard Griffin, the author of Black Like Me, was the keynote speaker at the rally, which drew an audience of more than 2,000. ${ }^{46}$ By 1964 the Davenport CIC had 900 members from different racial, ethnic, and religious backgrounds, and its monthly newsletter reached 1,400 households.

Through the Davenport CIC, Mexican American activists learned tactics of community organizing. Perry Ramirez, Henry Vargas, and Ernest Rodriguez were regular visitors to the barbershop in Davenport's black district where CIC president Charles Toney cut hair in one chair and Davenport NAACP president Bill Cribbs had the other. It was there that much of the local civil rights strategizing took place. ${ }^{48}$

Perhaps the most enduring legacy of the Davenport CIC was the Pacem in Terris Peace and Freedom award, established in 1964 in the wake of President John F. Kennedy's assassination. The CIC banquets were community events at which Davenport

45. Statement of the Davenport CIC, 5/11/1964; CIC brochure, undated; and "The Purpose of the CIC," undated, CIC 1960-65, all in McDaniel Collection. The Davenport CIC was founded in 1957. CIC folder, O'Connor Collection. Extensive records for the Davenport CIC can be found in the John L. Schneiders Collection at the Putnam Museum of History and Natural Science in Davenport. 46. Marvin Mottet to Ralph L. Hayes, 9/10/1962, CIC folder, O'Connor Collection; Davenport Morning Democrat, 8/23/1963; Times-Democrat, 8/24/1963. Quad Cities civil rights groups such as CORE and the Quad City Council on Human Rights helped plan the rally.

47. Davenport CIC annual report, 1964-1965, McDaniel Collection.

48. Rev. Marvin Mottet, interview with George McDaniel; Rev. Marvin Mottet, interview with author. 
Mexican Americans heard speeches from award recipients such as John Howard Griffin, Martin Luther King Jr., and Saul Alinsky, the hard-hitting Chicago community organizer who received the 1969 Pacem in Terris award at the height of the grape boycott activism in Davenport. ${ }^{49}$ Speaking at the banquet that year, Alinsky urged the audience to gain control over their lives by organizing: "Why organize? To get power. . . What is power? The ability to act." He concluded, "Reconciliation is when you get the power and the other side gets reconciled to it." ${ }^{\prime 50}$

Despite passage of the Civil Rights Act in 1964, de facto discrimination in housing, employment, and public accommodations persisted throughout the 1960s in Davenport, where an invisible color line ran from Locust Street south to the Mississippi River. Outside of that area, it was understood that African Americans and Mexican Americans would be denied service at drugstore counters, barbershops, beauty shops, and doctors' offices. Housing conditions had changed little in the area since the 1930s, when an extensive survey revealed slums and "blighted" areas, with many buildings in need of major structural repair. ${ }^{51}$ Mexican Americans who attempted to purchase homes in white neighborhoods often found that housing tracts had been "redlined." Realtors would not show houses to them, Anglos would not sell to them, and it was not uncommon for neighbors to circulate petitions to prevent families of Mexican descent from moving into all-white neighborhoods. ${ }^{52}$

A 1961 article in The Iowan described Davenport as "a city 'looking back over its shoulder, pleased at the specter of the Nineteenth Century, when thinking of human rights.'" The 1959 report of the Davenport Special Committee on Human

49. Catholic Messenger, 5/15/1969, 5/1/1969; Davenport CIC annual reports, 1963-1964 and 1964-1965, John L. Schneiders Collection. Cesar Chavez received the Pacem in Terris award in 1992. The Buzz on Campus, St. Ambrose University, 11/12/1992.

50. Catholic Messenger, 5/15/1969.

51. Iowa State Planning Board, Report on Housing, Davenport, Iowa (1935), 18; "Statement, Catholic Interracial Council of Davenport," 1/4/1962, CIC folder, O'Connor Collection.

52. "Housing Blight," Davenport CIC newsletter 5, December 1966, John L. Schneiders Collection; Henry Vargas, Salvador Lopez, Mary Vasquez Olvera, and Ernest Rodriguez interviews. 
Rights substantiated that perspective when it concluded that discrimination was widely practiced in Davenport and that "Negroes and Latin-Americans do not share the benefits of citizenship accorded to other citizens of Davenport." ${ }^{53}$

Governor Leo Hoegh's Commission to Study Discrimination in Employment in Iowa had also confirmed the existence of widespread discrimination in Davenport. ${ }^{54}$ Charles Toney, representing the NAACP, testified at the commission's 1956 hearings that, in Davenport, no African Americans or Mexican Americans were employed as clerks, teachers, police officers, or firemen, and that they were also denied entry into apprenticeship programs in the skilled trades. ${ }^{55}$

That little had changed for Mexican Americans since the 1930s was further evidenced by the 1963 observation of the Catholic bishop of Davenport: "One would like to believe that such discrimination in housing and employment does not exist in our own locality and in our own Diocese; but serious investigation has produced evidence that such discrimination does exist not only in regard to Negroes, but also to other races especially those who come from lands to the south of us." ${ }^{56}$

The City of Davenport bowed to years of pressure from the Davenport CIC in 1962, when it created a commission to handle complaints of discrimination. Henry Vargas served on the city's first Human Relations Commission (HRC) along with Charles Toney and nine others. ${ }^{57}$ Lacking the power to enforce its decisions, the commission depended on persuasion and education to accomplish its objectives. As a result, many considered it to be ineffective, and few cases were brought before it. Henry Var-

53. Wayne DeMouth and Joan Liffring, "Where the Negro Stands in Iowa," The Iowan 10 (Fall 1961), 4; Report of the Davenport Mayor's Special Committee on Human Rights, 1959, O'Connor Collection.

54. Ben Stone, "The Legislative Struggle for Civil Rights in Iowa, 1947-1965" (master's thesis, Iowa State University, 1990), 41-55.

55. Iowa Bystander, 6/21/1956; Henry Vargas interview, 9/26/2006.

56. To the Clergy and Laity of the Diocese of Davenport, 2/1/1963, CIC folder, 1960-65, McDaniel Collection.

57. Davenport City Council Minutes, 7/4/1962; Morning Democrat, 9/19/1962; list of first commissioners, 1962, in 1966-1968 binder, Accession \#2005-13, Davenport Civil Rights Commission (hereafter DCRC) Records, Richardson-Sloane Special Collections Center, Davenport Public Library. 
gas recalled that getting people to file complaints was "like pulling teeth"; although many Mexican Americans experienced discrimination in housing and employment, they remained silent. ${ }^{58}$

Throughout the 1960s, human relations commissions in cities across Iowa were widely regarded as ineffective. At a statewide workshop sponsored by the Iowa Civil Rights Commission in 1967, the chair of the Davenport commission protested that its ordinance lacked powers of enforcement. ${ }^{59}$ During that period, Davenport HRC member Rabbi Milton D. Rosenfeld resigned over the commission's refusal to adopt a fair housing ordinance, noting, "With the action we took on Monday night, we more than likely became the only Human Relations Commission in the entire country that moves backward on the question of Open Housing and works so hard at limiting its function." ${ }^{60}$

Henry Vargas was again serving on the Davenport HRC in January 1968 when the CIC presented the city council with its third request in five years for a fair housing ordinance. Civil rights groups in Davenport - the CIC, the NAACP, and LULAC - united in support of the ordinance and against the $\$ 500$ bond provision appended to it. When the local ordinance passed with the controversial $\$ 500$ bond provision intact, Vargas noted that LULAC was "deeply disappointed" and would "work with HRC and city council to find an amendment to it." A few months later, Vargas and Ernest Rodriguez - Council 10 delegates to the LULAC Iowa Supreme Council meeting - targeted the state law when they introduced a motion authorizing state director John Terronez to initiate federal court action to rescind the $\$ 500$ bond provision of the Iowa fair housing law. ${ }^{61}$

58. Henry Vargas, telephone interview with author, Davenport, 2/1/2008; Morning Democrat, 9/25/1962; "Discrimination and Davenport Mexicans," Labor 26, no. 16A (November 1963), St. Ambrose University Library Archives.

59. Des Moines Register, 9/28/1967. Only Des Moines and Waterloo had "broad human rights ordinances enforced by commissions with budgets and staffs."

60. Times-Democrat, 9/26/1967, 9/27/1967; "Reasons for the Resignation of Rabbi Milton D. Rosenfeld from the Davenport Human Relations Commission," ca. 9/26/1967, Committee Reports, 1966-1968 binder, DCRC Records.

61. Times-Democrat, 1/28/1968; Sunday Times-Democrat, 11/12/1967; "Housing," 3/20/1968, in newspaper clippings, 1966-1968 binder, DCRC Records; LULAC Glances, 11/9/1968, LULAC 10 Records. The Davenport proposal went beyond Iowa's fair housing law, enacted the previous year, in that it did not 
By the late 1960s, LULAC Council 10 members had gained experience in confronting the underlying issues that contributed to segregation and discrimination. During his tenure on the Davenport HRC, Ernest Rodriguez, a union member and packinghouse worker at Oscar Mayer, took up the proposal for a paid full-time director for the commission and worked to improve police-community relations. Like others, Rodriguez believed that the work of the commission had been hampered by the lack of a director, noting, "We are nibbling at problems we should be taking big bites out of." ${ }^{62}$ On the issue of discrimination in education, Rodriguez brought his concerns directly to the Davenport School Board. Arguing that children of minority groups were victims of "discriminatory middle-class thinking" in a system that perpetuated low achievement among disadvantaged children, he challenged the board to ask teachers to "lift the veil of whatever obscures your vision and look beyond the purely superficial appearances, look into our hearts, look into our minds, read about us, know us, understand us." ${ }^{13}$

The activism of Davenport Mexican Americans during the 1960s is all the more remarkable when understood in the context of their full-time employment as blue-collar workers who, for the most part, did not hold elected offices in their local unions. Their ability to attend meetings and rallies and engage in other forms of activism was constrained by shift schedules, time clocks, and supervisors. During his tenure on the Davenport HRC in the 1960s, for example, Salvador Lopez was moved to the second shift, making it very difficult for him to attend com-

require a $\$ 500$ bond to be posted when a complaint was filed. The $\$ 500$ bond provision meant that the plaintiff had to pay $\$ 500$ in cash to the city before a complaint could be filed. As Representative June Franklin, the only African American woman in the Iowa General Assembly in 1967, pointed out, "No bonding company will underwrite the $\$ 500$, 'which means $\$ 500$ cash is required.'" Quoted in Suzanne O'Dea Schenken, Legislators and Politicians: Iowa's Women Lawmakers (Ames, Iowa, 1995), 116.

62. Times-Democrat, 12/10/1968, 11/10/1969; Ernest Rodriguez, "The Mexican American People of the Quad City Area," undated, Ernest Rodriguez Papers. After a protracted struggle, Davenport NAACP president Bill Cribbs was named director of Davenport HRC. Times-Democrat, 11/11/1969, 8/20/1970.

63. "Delivered to the Davenport school board by John Terronez in my stead," ca. 1969, "Impressions," Ernest Rodriguez Papers. 
mission meetings. When Ernest Rodriguez was denied release time to attend a meeting of the Davenport School Board, he requested that the board hold its meetings in the evenings in order to "be more convenient for working people."

As the grape boycott gained momentum nationally, a strong Mexican American leadership in Davenport was strategically situated to play a significant role. John Terronez, a member of Postal Workers Local 91, had emerged as an outspoken and effective voice for Mexican Americans throughout Iowa. Elected as state director of Iowa LULAC in 1968, the 30-year-old Terronez rallied Iowa LULAC members to mobilize for change, speaking openly of ethnic and racial discrimination, and forcing a public dialogue on previously ignored concerns: "Yes, Virginia, there is an ethnic minority group called Mexican Americans, but don't tell anyone because it's the best kept secret in the country. Besides, they are happy with things, one's never complained to me yet, and why should they? They make good money in the foundries and factories." ${ }^{65}$

In 1968 John Terronez filed a complaint with the Iowa Civil Rights Commission (ICRC). The complaint stemmed from an incident when Davenport LULAC members were overcharged at a Muscatine bar. When efforts to resolve the discrepancy through Muscatine city officials failed, Terronez took the matter to the ICRC. ${ }^{66}$ In his capacity as state director of Iowa LULAC, Terronez also expressed concern over the lack of Mexican American representation on the commission, a situation that ICRC director Alvin Hayes attributed to the state's requirement that its commissioners have a four-year college education and that "no Mexican-American with that qualification had made application with the commission." ${ }^{67}$

64. Ibid.; Fr. Jack Wolter, chair, Davenport HRC, to Salvador Lopez, 7/12/1967, Correspondence, 1966-1968 binder, DCRC Records.

65. LULAC Glances, 11/9/1968, 6/2/1969.

66. LULAC Glances, 11/9/1968. According to LULAC records, this was the first complaint filed by a Mexican American with the ICRC. However, due to the nature of the requirements governing record keeping at the ICRC, I cannot confirm that claim. The ICRC was founded in 1965; for details of its formation, see Ben Stone, "The Legislative Struggle for Civil Rights in Iowa."

67. Times-Democrat, 11/10/1969; LULAC Glances, 11/9/1968. 
Terronez's vision for Iowa LULAC embodied the civil rights aspirations of the national organization as he stressed the need for "working" LULACs rather than "social" organizations. ${ }^{68} \mathrm{He}$ was able to bridge the conservative ideology of many Iowa Mexican Americans and press for opportunities inherent in the civil rights legislation of the day. Despite criticism from one Iowa LULAC council for his too frequent use of the term "Brown Power," Terronez was nonetheless elected to a second term as state director in $1969 .{ }^{69}$

The type of coalition building and grassroots community organizing required for the grape boycott campaign mirrored the type of organizing that had long been the rule of the day for civil rights activists in Davenport. By the late 1960s, Davenport LULAC leaders had become increasingly effective at raising the visibility of the issues affecting the area's Spanish-speaking residents. As they took up La Causa, they were energized, angry, and confident in their ability to make change through the coalition tactics they had learned as leaders of Iowa's most active LULAC council. The boycott and unionization strategy proposed by Cesar Chavez was one in which the working-class leadership of LULAC Council 10 was well grounded. This was their fight, and, according to one Council 10 member, its overriding significance lay in the fact that Cesar Chavez and the grape boycott movement "gave us an identity."

THE EARLY LIFE EXPERIENCES of Davenport Mexican Americans as agricultural laborers, trade unionists, and activists proved relevant to their ability to take up the fight for the rights

68. LULAC Glances, ca. January 1969; Terronez, report on his November 10, 1968, visit to Cedar Rapids, report of state director, March 1969, LULAC 10 Records. Following the 1968 meeting regarding the formation of a Cedar Rapids LULAC council, Terronez noted, "Evidently the Mexican Americans in Cedar Rapids have no problems. They consider themselves 'anglo' BUT all I saw were brown people. . . . Needless to say that we already have too many socially oriented members of LULAC."

69. Good and Welfare Report, Proceedings of Twelfth Annual LULAC Convention, Des Moines, 6/14/1969, LULAC 10 Records.

70. Ernest Rodriguez, interview with author, Davenport, 5/14/2007, IWA; Ernest Rodriguez, "The Chicano Movement," "Impressions," Ernest Rodriguez Papers. 
of grape pickers in California. Moreover, it enabled them to draw attention to the needs of Iowa's permanent Spanish-speaking residents as well as the rights of temporary Tejano migrant workers, who had long been an invisible, but vital, component of the state's agribusiness. When widespread publicity around the national grape boycott coincided with a fiercely contested effort to pass Iowa's first migrant worker legislation, Davenport Mexican Americans were strongly positioned to work for $\mathrm{La}$ Causa while, at the same time, harnessing the energy of that movement to improve conditions for Mexican Americans locally and throughout the state. ${ }^{71}$

At the heart of the initiative to support the grape boycott in Iowa was the Davenport LULAC Council, which had ten years of experience under its belt when it organized the Quad City Grape Boycott Committee in December 1968. In the young and outspoken John Terronez, the council had its own charismatic leader who in many ways embodied the spirit of Cesar Chavez and the emerging Chicano movement. As one LULAC member explained, "John was really persuasive. . . . [He] had a lot of moxie. He was smart and aggressive and really could think on his feet." ${ }^{72}$

In December 1968, Terronez attended a regional conference in Gary, Indiana, where national LULAC president Roberto Ornelas encouraged Midwest LULAC councils to become more active in the California grape boycott. Council 10 responded by forming the Quad City Grape Boycott Committee and urging residents in the area to refrain from buying California table grapes. $^{73}$

To help solidify local support for the boycott, Eliseo Medina, the United Farm Workers Organizing Committee (UFWOC)

71. Works that do not reference Iowa but provide context for understanding what happened in Iowa include Marco G. Prouty, César Chávez, the Catholic Bishops, and the Farmworkers' Struggle for Social Justice (Tucson, AZ, 2006); Badillo, "The Catholic Church and Mexican-American Parish Communities"; and Vargas, Labor Rights Are Civil Rights.

72. Ernest Rodriguez interview, 8/6/2005.

73. Times-Democrat, 12/16/1968; Report of state director of Iowa LULAC, undated (ca. March 1969), LULAC 10 Records; "December 7, 1968, Midwest Conference, Gary, Indiana," LULAC Glances, undated (ca. January 1969); Minutes of LULAC 10, November 1968, LULAC 10 Records. 
boycott coordinator for the Midwest region, traveled to Davenport. While Medina addressed a meeting at the LULAC club, John Terronez and Ernest Rodriguez, chair and cochair of the Quad City Grape Boycott Committee, solicited support from the Quad City Federation of Labor, AFL-CIO. ${ }^{74}$

The local grape boycott campaign drew support from a broad coalition of organizations and activists, including the Iowa Council of Churches, local civil rights groups, local unions, and students. Putting their collective energy and experience to work for La Causa, they laid plans for a boycott rally to be held in Davenport in January 1969, inviting the national UFWOC secretary-treasurer, Antonio Orendain, to officially launch the Quad City grape boycott campaign. ${ }^{75}$

Approximately 50 people gathered at the Davenport rally, including representatives from local unions, civil rights organizations, and the Illinois Migrant Council. Remarking on the enthusiasm of the day, Terronez announced, "If we have to go all the way, we'll have pickets and sit-ins. . . . And the pickets won't be all one color. They'll be black and white and brown picketers. ... When we bring the races together like that we're accomplishing something."

Ernest Rodriguez attended a Midwest strategy meeting in Colfax, Iowa, where plans were unveiled for International Grape Boycott Day, designed to coincide with the beginning of the grape harvest. Also attending the Colfax meeting were UFWOC boycott coordinator Eliseo Medina and Don Q. Lewis, the vicepresident of the Iowa Federation of Labor (IFL), AFL-CIO, who

74. Times-Democrat, 12/19/1968, 2/26/1969; Minutes, Quad City Grape Boycott Committee (QCGBC), 4/18/1969, LULAC 10 Records; QCGBC newsletter, 4/27/1969, ibid.; LULAC Glances, October-December 1968. For more on the grape boycott campaign in the Midwest, see Jerry B. Brown, "The United Farm Workers Grape Strike and Boycott, 1965-1970: An Evaluation of the Culture of Poverty Theory" (Ph.D. thesis, Cornell University, 1972), 182-92.

75. QCGBC minutes, 1/11/1969, LULAC 10 Records. Organizations supporting the boycott included the Davenport CIC, the Scott County Young Democrats, the Muscatine Community Effort Organization, LULAC Council 10, and the Davenport chapter of the American GI Forum

76. Times-Democrat, 1/12/1969; Iowa State director's report to LULAC Supreme Council meeting, Joliet, IN, March 1969, LULAC 10 Records; Henry Vargas interviews, 9/26/2006 and 10/3/2006. 
had recently prepared to support the grape boycott in a public debate. $^{77}$

LULAC Council 10 leaders were frustrated in their efforts to generate broad support for the grape boycott in Iowa. ${ }^{78}$ Despite encouragement from Council 10 for LULAC members in other parts of Iowa to - in the words of John Terronez — "jump in with both feet" and set up a grape boycott committee, none did. Terronez remained perplexed that Council 10 was the only LULAC council in Iowa to form a boycott committee.

It is a shame that the Mexican American in Iowa in certain cities are [sic] not involved more in just causes such as the grape boycott. These are usually the same people who complain the loudest that LULAC is not doing anything for the "RAZA." . . These are the same people who refuse to believe that Civil Rights also means Mexican Americans and that discrimination does not just apply to our black brothers, but also applies to the Mexican American. It is time we realized that although we are classified as white, we are brown, and as a result we are not given the same opportunities as our white friends and neighbors. And if we continue in our dream of equality by being patient and quiet, then let me tell you that the time is fast approaching when we will not even be getting the same opportunities that our black brothers will have. If we do not stand up and voice our opinion on the issues of today that concern us, then we won't have to worry about the issues of tomorrow because by then we won't even be included in these issues. ${ }^{79}$

In the Quad Cities, however, support for the grape boycott remained strong. By April 1969, more than 20 organizations were actively supporting the campaign, and the bishop of the Davenport Diocese had endorsed the boycott in an official state-

77. LULAC Glances, 3/26/1969; Don Q. Lewis to Cesar Chavez, 2/14/1969, folder 27, box 109, Iowa Federation of Labor, AFL-CIO, Records, Iowa Labor Collection, SHSI, Iowa City; "Northcentral boycott meeting," Colfax, Iowa, March 7-9, 1969, ibid. The Colfax meeting was attended by boycott supporters from Wisconsin, Minnesota, Nebraska, North Dakota, and Iowa.

78. Report of Vice-President, 7/7/1969, 14th Annual Convention, Reports, folder 11, box 38, Iowa Federation of Labor, AFL-CIO, Records; Report of Boycott Committee, 9/9/1969, ibid. The Iowa Federation of Labor Boycott Committee recommended implementation of a statewide "don't buy grapes day," noting that the grape boycott campaign was "bogged down in Iowa."

79. LULAC Glances, 3/26/1969. 
ment in the Catholic Messenger. At least seven stores, including A\&P, had stopped carrying the grapes; only Murray's Super Valu and Jacob's Super Valu in Davenport continued to stock them. ${ }^{80}$ On International Grape Boycott Day — May 10, 1969 approximately 40 picketers turned out to support the boycott in the Quad Cities, shouldering signs that read, "Viva La Causa," and "Justice and Dignity for the Farm Workers." Churches and unions provided critical public and financial support for the campaign, but it was primarily a small group of LULAC members, GI Forum members, and St. Ambrose College students, imbued with "that spirit," who regularly stood picket duty. ${ }^{81}$

Church support for the grape boycott drew harsh criticism from area farmers such as Donald Klindt, president-elect of the Scott County Farm Bureau. The support of the Iowa Council of Churches for the grape boycott troubled many farmers who did not believe that a "church in a rural community should be supporting an action that is not in the best interests of its members." Farm Bureau members saw church support for the grape boycott as an attempt to force growers to insist that their workers join the United Farm Workers. Moreover, the Iowa Farm Bureau Association believed that picketing supermarkets constituted a secondary boycott, which set a "dangerous precedent." Stiff opposition from the Farm Bureau bolstered the determination of Davenport activists to maintain a strong offensive. As Terronez saw it, "The [John] Birchers and Farm Bureau have made it perfectly clear, they like the cheap labor supply of Mexican American farm workers and they intend to keep it that way by breaking the grape boycott and Cesar Chavez." ${ }^{\prime 2}$

80. LULAC Glances, 3/26/1969; QCGBC minutes, 4/1/1969, LULAC 10 Records; Times-Democrat, 4/5/1969.

81. Catholic Messenger, 5/15/1969; Henry Vargas interview, 9/26/2006; Henry Vargas telephone interview, 2/18/2008; Ernest Rodriguez, "The Year 1970," in "Impressions," Ernest Rodriguez Papers; QCGBC minutes, 1/11/1969 and 4/18/1969, LULAC 10 Records.

82. Times-Democrat, 12/20/1968; LULAC Glances, October 1969. A secondary boycott is an attempt to influence the actions of one business by putting pressure on another; it is the application of economic pressure by a union against an entity or person with which the union has no dispute regarding its members' terms or conditions of employment in order to cause that entity or person to stop doing business with the employer that the union does have a dispute with over terms or conditions of employment. The intent of the grape boycott 


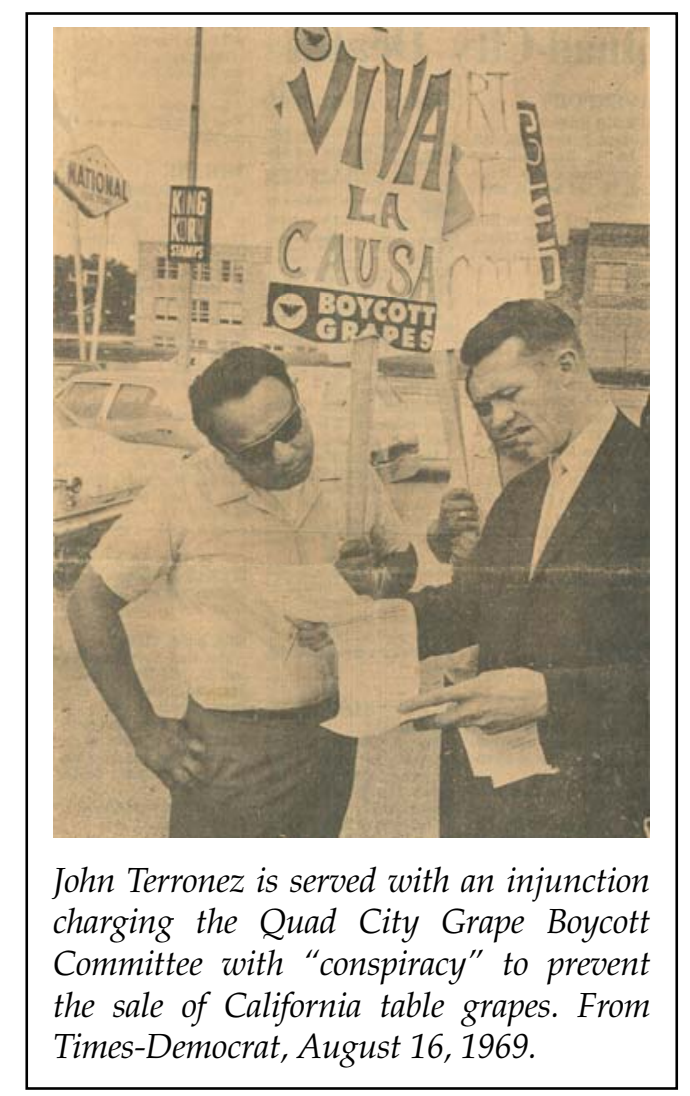

As rank-and-file trade unionists, leaders of the local grape boycott campaign understood the unionization and boycott strategy proposed by Cesar Chavez. They supported the grape boycott - at a time when many Mexican Americans in the community and throughout Iowa did not - by upholding their right to picket and put a banner up in front of a store to protest its handling of an unfair labor product. They could negotiate effectively around complex issues of informational picketing and secondary boycotts and understood the labor logic of UFWOC lawyers who argued that, if farm workers were excluded from the protective provisions of the National Labor Relations Act

was to put economic pressure on Delano growers in order to bring them to the bargaining table and recognize UFWOC as the sole bargaining agent for Delano grape pickers. 
(NLRA), they must also be exempt from the Taft-Hartley amendments to the NLRA that proscribed secondary boycotts. ${ }^{83}$

The high profile of the Delano grape strike and boycott enabled Davenport Mexican Americans (by then identifying themselves as Chicanos) to combine forces with progressive Anglos to draw attention to the deplorable conditions faced by migrant workers in Iowa's own agricultural industry. The extensive use of migrant labor was a longstanding tradition on many Iowa farms, particularly in the Muscatine area, where the H. J. Heinz Company operated a large cannery ${ }^{84}$ Iowa agricultural laborers, like the Delano grape pickers, were excluded from the pro-labor legislation of the New Deal era. As a result, they were not covered by the organizing and bargaining protections of the NLRA or by the minimum wage, overtime, and child labor provisions of the Fair Labor Standards Act. ${ }^{85}$

Major publicity about the abuse of Tejano migrant workers in Iowa broke in the Des Moines Register in 1966. "The Shame of Iowa: Migrant Workers' Plight," the first in a series of articles,

83. Times-Democrat, 8/16/1969; LULAC Glances, October 1969; Prouty, César Chávez, 28.

84. Richard De Vere Horton, "Spanish-Speaking Migratory Agricultural Laborers in the Area of Muscatine, Iowa" (M.A. thesis, University of Iowa, 1963), 16-24; Muscatine Migrant Committee, Annual Report, 1966, 25-26, University of Iowa Libraries. The four main counties where farmers contracted with Heinz for tomatoes were Cedar, Muscatine, Louisa, and Scott. See also Anne B. W. Effland, "The Emergence of Federal Assistance Programs for Migrant and Seasonal Farm Workers in Post-World War II America" (Ph.D. thesis, Iowa State University, 1991), chap. 5.

85. In 1966 Congress amended the FLSA to limit the minimum wage exclusion of agricultural laborers. However, the law excluded farm workers employed on family farms. The definition of a family farm was "an employer who did not during any calendar quarter, during the preceding calendar year, use more than five hundred man-days of agricultural labor." Marc Linder, Migrant Workers and Minimum Wages: Regulating the Exploitation of Agricultural Labor in the United States (Boulder, CO, 1992), 294. Migrant workers employed by tomato growers in Muscatine worked in June, August, and September, which, because of the way the season was divided, straddled the calendar quarters of April-June and July-September. This enabled growers to avoid the 500 manday maximum and meant that migrant workers' wages in Muscatine remained significantly below the minimum wage. See Conóceme en Iowa: The Official Report of the Governor's Spanish Speaking Task Force Submitted to Governor Robert D. Ray and the 66th General Assembly (copy in IWA), "Table XXX, Work Periods Crops and Wages in Iowa (By County)," 38, "Migrant Wages: Hourly Basis," 42-43, and "Migrant Wages Piece Rate Basis," 43. 
described unsanitary and overcrowded shelters such as hog houses, chicken sheds, and abandoned school buses that were home to some Iowa migrant workers. The media coverage had a profound impact on public opinion and proved crucial to winning the battles in the Iowa legislature over the passage of the state's first migrant worker legislation in 1967 and 1969. Many Iowans, previously unaware that migrant workers were employed in the state, were shocked by photographs and testimonies provided through newspaper coverage. They now identified farm labor in Iowa with the powerful CBS documentary, "Harvest of Shame," that had aired in $1960 .{ }^{86}$

For Henry Vargas and other Mexican American activists in Davenport, the issues of California grape pickers fused with issues faced by migrant workers in Iowa. Both were a powerful reminder of the inequities they had endured growing up in the barrios of the Quad Cities.

Some of us had lived at Cook's Point. So we thought it wasn't right. So we thought it was something we had to do. ... No water, no electricity, and we had to get out there and work to make money. And we knew what it was like. And we seen some of the housing in Muscatine. And we went down there and the farmers were up in arms over it. ... What them people had to go through down there. ${ }^{87}$

The campaign for migrant worker legislation in Iowa unfolded concurrently with the California grape boycott, each lending legitimacy to and fueling the other. No laws governed migrant housing or field sanitation in Iowa until 1969, and the use of migrant child labor was common practice in Muscatine, where "very young children between the ages of five and ten years were actually in the fields on a full-time basis working with their parents in the picking of tomatoes. ... the work these children were doing was hard manual labor." ${ }^{18}$

86. Des Moines Register, 10/23/1966; John Tapscott, telephone interview with author, Indianola, 4/12/2008. Representative John Tapscott sponsored the 1967 and 1969 migrant worker bills in the Iowa legislature.

87. Henry Vargas interview, 9/26/2006.

88. Leo Ballard to John Tapscott, 4/13/1967, box 13, Elizabeth Shaw Papers, IWA. For a description of wage garnishing, bonus system, and other abuses, see Shirley Sandage, statement before the U.S. Commission on Civil Rights at Davenport, 10/18/1969, box 1, Shirley Sandage Papers, IWA. 
In an agrarian state with a Republican-dominated legislature closely tied to the interests of the Farm Bureau and corporate agriculture, migrant child labor legislation did not pass the Iowa General Assembly until 1967. As the director of the Iowa Development Commission noted, "The Commission has been strongly urged by Muscatine Development Corp. (because of H. J. Heinz - who are very upset on this) to take a position opposing the bill." These observations foreshadowed what proved to be a protracted and contentious struggle. ${ }^{89}$

The proposed bill would have made it illegal to employ migrant children under the age of 14 in farm labor in Iowa. ${ }^{90}$ With 90 Republicans and 34 Democrats in the Iowa House in 1967, the bill needed strong bipartisan support to even make it out of committee. It faced considerable opposition from the H. J. Heinz Company and tomato growers in Louisa and Muscatine counties, who feared it would put Iowa growers at an unfair disadvantage with neighboring Illinois. ${ }^{91}$ In addition, Iowa growers, aware of the union organizing effort under way in Delano, California, feared unionization of "their" workers. The growers' interests were represented by David Stanley, a Republican senator from Muscatine, known by colleagues as a "shrewd manipulator" in the halls of the Iowa legislature. ${ }^{92}$

When the severely weakened and amended bill eventually passed the House after more than two months of heated debate, it permitted children under the age of 14 to work in the fields

89. "To Mr. Les Holland from Carroll E. Worlan re: Bills on House Calendar (4/25/67) of interest to IDC, 27 April, 1967," box G22, Harold Hughes Papers, Special Collections, University of Iowa Libraries, Iowa City. Les Holland was Iowa Governor Harold Hughes's administrative assistant. Carroll Worlan was the director of the Iowa Development Commission, which was established in 1945 and was the forerunner of today's Department of Economic Development.

90. Des Moines Register, 4/4/1967.

91. Migrant child labor legislation passed in Iowa six years earlier than in neighboring Illinois, heightening the controversy surrounding the passage of the Iowa bill, particularly in the Muscatine area. Illinois's first migrant child labor legislation passed in 1973. 1973 Illinois Laws, Public Act 78-607 at 1828, 1829.

92. Des Moines Register, 4/4/1967; recording of House debate of HF178, audiocassette \#449, Shirley Sandage Papers, IWA; John Tapscott interview. Shirley Sandage, director of the Mason City-based Migrant Action Program, was a leading, but purposely behind-the-scenes, proponent of HF178. 
outside of school hours. ${ }^{93}$ LULAC Council 10 members responded by petitioning Scott County Senators Joseph Cassidy and Roger Jepsen to "press for a stronger bill in the Senate," and at the state LULAC convention in Davenport, Henry Vargas suggested organizing a national boycott of H. J. Heinz Company products. $^{94}$

The Senate responded to pressure to strengthen the bill by returning it in its original form to the House, where it was expected to "die for lack of approval." ${ }^{195}$ But at the end of June the House passed a compromise amendment, which was quickly and unanimously approved in the Senate. The new bill prohibited migrant children under 10 from working in the fields at any time and barred growers from "knowingly" employing children under the age of 14 during school hours. The use of the word knowingly radically reduced farmers' liability for failing to heed the legislation as they could always plead ignorance of the actual age of any child they employed, thus placing the burden of responsibility with the children's parents. ${ }^{96}$

LULAC Council 10 was more centrally involved in the effort to pass migrant worker legislation in 1969, when two bills, again sponsored by Representative Tapscott, were before the Iowa General Assembly. The first would strengthen the enforcement of the 1967 migrant child labor law by deleting the word knowingly; the second would establish minimum health and safety standards for the housing of migrant workers in Iowa. Both bills were contentious and, again, faced an uphill battle in the Iowa legislature. ${ }^{97}$

\footnotetext{
93. Four supporters of the original bill (Glenn, Johnston, and Maloney of Polk County and Hill of Marshall County) voted no on the amended bill, explaining, "The amendment that became the bill not only destroyed the original bill, but will give those employing migratory workers the legal right to work and exploit young children of the tender ages of 5, 6, and 7 and so on up to 14 during off-school hours even though it is morally wrong to do so." See 62nd General Assembly, House Journal, 1246; Muscatine Journal, 5/4/1967; Des Moines Register, 6/20/1967, 6/21/1967.
}

94. Des Moines Register, 6/3/1967; Muscatine Journal, 5/4/1967, 6/15/1967.

95. Des Moines Register, 6/15/1967; Muscatine Journal, 6/15/1967.

96. Des Moines Register, 6/20/1967, 6/23/1967; Muscatine Journal, 6/23/1967; 62nd General Assembly, House Journal, 2117.

97. Times-Democrat, 2/27/1969; Des Moines Register, 3/18/1969. 
To assert the "lobbying power" behind the two new migrant protection bills, proponents planned a demonstration in front of the Statehouse. The Iowa Federation of Labor and United Auto Workers responded by chartering buses to bring supporters, including Quad City Mexican Americans, to Des Moines from across the state. About 1,500 demonstrators converged in Des Moines on March 19, 1969, when "labor marched on the state capitol for the first time in two decades." At the rally, Representative Tapscott called for a boycott of H. J. Heinz Company products. Looking back on the "historic" march, Terronez noted, "it gave us a feeling of satisfaction, contentment and accomplishment. But best of all it gave us a feeling of 'solidarity.' '"98

As parallels between migrant workers in Iowa and farm workers in California became clear, local organizations stepped up their efforts to work for change. In the weeks following the rally, leaders of the Muscatine Community Effort Organization (CEO), a group of 150 settled-out migrant workers, together with leaders of LULAC Council 10 and Representative Tapscott, began planning the official start of a "tomato boycott," which they hoped would become a national boycott of $\mathrm{H}$. J. Heinz Company products. Muscatine CEO members, who sought to improve conditions in the approximately 200 migrant labor camps established each year in Iowa, proclaimed, "Let us leave the chickens in the chicken shacks and the pigs in the pig pens ... and let's join with the great boycott of grapes with CESAR CHAVEZ by C.E.O. of MIDWEST."

A majority of the Muscatine CEO members were former Mexican American migrant workers from Texas, inspired by Cesar Chavez to fight for the rights of those who continued to work in the migrant stream. Shortly after the Des Moines rally,

98. Times-Democrat, 3/20/1969; Des Moines Register, 3/20/1969; LULAC Glances, 6/2/1969. Tapscott described Edris "Soapy" Owens (UAW), Bill Fenton (Machinists), and Don Rowan (Iowa South Central Labor Council) as strong supporters of the legislation (Tapscott interview). Owens's name also appears in QCGBC documents. For an account of labor's earlier march on Des Moines in 1947, when 150,000 turned out to protest the passage of the Iowa right-to-work bill, see Stromquist, Solidarity and Survival, 158-59.

99. Frank Perez to Henry Vargas, 3/26/1969, LULAC 10 Records; John Tapscott interview; "News Article by CEO of the Midwest," undated, LULAC 10 Records; Times-Democrat, 4/1/1969, 4/8/1969. 
IS THE PRICE TOO HIGH?

The Earth buds forth its Savior.

\author{
SPRING! JOY!
}

The Eorth is budding with life, and soon the migrant workers will be back in lowo's rich fields to perform stoop labor-bending, hoeing, weeding, harvesting.

Their living conditions are generally deplorable. Let's act with Christian concern to change these conditions.

Bills to improve housing and sanitation in migrant camps and to regulate child labor ore awaiting action in the lowa Legislature.

Opponents of these bills include growers, legislators, and lobbyists from the Muscatine areo, WHERE H. J. HEINZ CO. HAS A CANNING PLANT.

\section{DON'T BUY HEINZ PRODUCTS}

until the Legislature acts to correct deplorable conditions afflicting migront workers in lowo.

Contact the members of the Senate and House. Tell them you are a Christion who supports:

\section{HF 146 - TO REGULATE MIGRANT CHILD LABOR. \\ HF 317 -TO IMPROVE HOUSING AND SANITARY CONDITIONS IN MIGRANT CAMPS.}

"Whatsoever you do to the least of My brothers..."
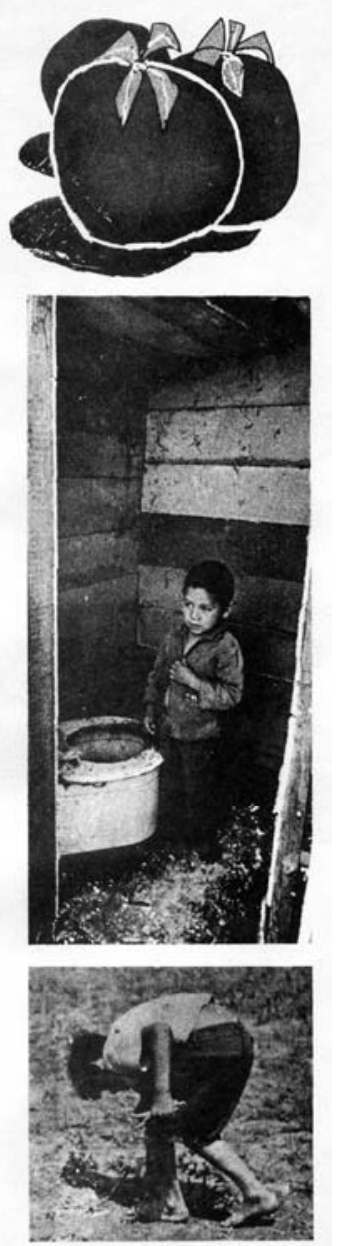

Leaflet distributed at churches in Des Moines, Davenport, and Mason City on Easter Sunday, 1969. From LULAC Council 10 Records, Iowa Women's Archives.

CEO leaders attended a meeting of the Quad City Grape Boycott Committee, which unanimously endorsed the Heinz boycott. Even the president of the Quad City Federation of Labor voted 
to endorse the boycott after originally arguing that it would be detrimental to the 700 members of his local union (AMCBW Local 431) employed at the H. J. Heinz facility in Muscatine. ${ }^{100}$

Working together, the organizations planned to "hit Heinz hard" and envisioned a Midwest farm worker movement in support of a "great boycott against Heinz." The flyer, "'Boicoteo! Rayo de Esperanza para el Campesino" [Boycott! Ray of Hope for the Farm Worker], written in Spanish by Ernest Rodriguez, underscored the connection between Delano and Muscatine and appealed to racial, ethnic, and labor solidarity: "La huelga y boicoteo de uvas tiene su origin en Delano, California pero en verdad es una lucha para la liberación de la pobreza de todos los que trabajan en la cosecha del campo" [The grape strike and boycott has its origin in Delano, California, but in reality it is a struggle to liberate from poverty all those who work in the harvest]. ${ }^{10}$

The launch of the "tomato boycott" was planned for Easter Sunday 1969, with a mass leafleting at Des Moines, Davenport, and Mason City churches. The UAW and other groups planned to distribute 100,000 leaflets urging congregations to boycott Heinz in support of migrant worker legislation. Meeting at the Midwest LULAC conference in Davenport the next week, Council 10 put forward a resolution to boycott Heinz, which delegates officially endorsed, and moved to present a proposal for a Heinz boycott at the national LULAC convention in California in June. Despite a promising start, the Heinz boycott failed to gain momentum; a pre-existing agreement between the H. J. Heinz Company and the national LULAC office precluded national LULAC support for a Heinz boycott. Nonetheless, the Heinz boycott was an effective short-term strategy for raising awareness in Iowa of the needs of Mexican American migrant workers within its own borders. ${ }^{102}$

100. QCGBC minutes, 3/31/1969, 4/1/1969; QCGBC newsletter, 4/27/1969, LULAC 10 Records.

101. LULAC Glances, October 1969, LULAC 10 Records; Ernesto Rodriguez, “¡Boicoteo! Rayo de Esperanza para el Campesino," QCGBC newsletter, 4/27/ 1969, 5, ibid.

102. QCBC Minutes, 4/1/1969; Catholic Messenger, 4/10/1969; Times-Democrat, 4/13/1969; LULAC Glances, 6/2/1969. According to LULAC Council 10 Records, the national agreement did not apply to Iowa. 
Upon his return from the national LULAC convention in California, John Terronez announced his appointment to the Iowa State Advisory Committee to the U.S. Commission on Civil Rights. ${ }^{103}$ Terronez, the first Mexican American to serve on the committee, was joined the next year by Davenport activists Ernest Rodriguez, John L. Schneiders, and Father Bill O'Connor. Terronez acted swiftly to bring the needs of Iowa Mexican Americans to the committee's attention. At his first meeting, in July 1969, he called for an investigation into the conditions of Spanish-speaking Iowans. He then provided a detailed report informing the committee of the lack of any accurate population figures for Iowa's Spanish-speaking population, who faced problems in housing, employment, migrant health, education, and police relations at the state and local level. The Iowa State Advisory Committee responded by calling for an open meeting of the committee to be held in Davenport on October $18,1969{ }^{104}$

LULAC worked with members of the Muscatine CEO and migrant action programs to coordinate the meeting. The ensuing report, "¿Adonde Vamos Ahora?" [Where are we going now?], called for an investigation into the numbers of Spanishspeaking residents in Iowa, both permanent and migratory, and for educational programs to meet the needs of Spanish-speaking students, including bilingual preschools and the appointment of Spanish-speaking teachers. The report also demanded stricter enforcement of affirmative action regulations and legislation to uphold the rights of migrant workers and the poor.

As the Delano grape strike drew to a successful conclusion in July 1970, Davenport Mexican Americans continued to use boycott strategies to work for change. Mary Terronez coordinated an effort by Davenport Mexican American women to protest discriminatory hiring practices at Oscar Mayer by picketing the plant and calling for a boycott of the company's products.

103. LULAC Glances, October 1969.

104. “¿Adonde Vamos Ahora? [Where are we going now]: A Report on the Problems of the Spanish Surnamed and Migrant Population in Iowa prepared by the Iowa State Advisory Committee to the U. S. Commission on Civil Rights," September 1970, LULAC Council 10 Records.

105. Ibid. 
The protest resulted in the immediate hiring of several Mexican American women. ${ }^{106}$

In November 1970 Ernest Rodriguez left his packinghouse job to fill a full-time position in Davenport as director of the newly created Area Board for Migrants, funded by the dioceses of Davenport, Peoria, and Rockford. In that position Rodriguez initiated an immigration counseling service and fought for a bill proposing an Iowa Spanish-speaking task force. The report compiled by members of the task force, on which Rodriguez served, led to the creation of the Iowa Spanish Speaking Peoples Commission in 1976, the forerunner of the Iowa Commission on Latino Affairs. ${ }^{107}$

During the 1970s, LULAC Council 10 leaders built on a tradition of activism, looking beyond Iowa to work collaboratively with other midwestern Chicanos. They took part in forming the Midwest Council of La Raza in 1970, with Henry Vargas and Ernest Rodriguez serving on the organization's board of directors in 1971. ${ }^{108}$ John Terronez's leadership skills were recognized in 1970 when he was recruited to work as a mediator in the U.S. Justice Department's Community Relations Service, a position he held until his death in 1997.

106. Ernest Rodriguez interview, 9/19/2006; Dolores Garcia interviews, Davenport, 9/22/2005 and 9/26/2006; Mary Terronez interview, 10/10/2006; "Not Everybody Loves an Oscar Mayer Wiener," Ain't I a Woman: A Midwest Newspaper of Women's Liberation, 8/21/1970, IWA; Times-Democrat, 8/12/1970, 8/13/1970.

107. Catholic Messenger, 10/15/1970, 11/5/1970; untitled report of ABM, 1974, Muscatine Migrant Committee Records, IWA; Ernest Rodriguez EEO resumé, Ernest Rodriguez Papers; Ernest Rodriguez interview, 9/19/2006; Ernest Rodriguez, chair, Governor's Spanish-speaking Task Force, to Governor Ray, ca. 7/6/1976, regarding Senate File 1336, Iowa General Assembly, 1976, Spanish Speaking Commission folder, Ernest Rodriguez Papers.

108. LULAC Glances, 5/26/1970; Registration for Urban Studies Mexican American Conference, University of Notre Dame, April 17-18, 1970, Ernest Rodriguez Papers; Midwest Council of La Raza Executive Board and Board of Director's meeting, November 12-13, 1971, Muscatine Migrant Committee Records, IWA; Santillán, "Latino Politics," 109.

109. Quad-City Times, 11/16/1997, 8/5/1979; LULAC Glances, 5/26/1970. John Terronez worked for the U. S. Justice Department from 1970 until his death in 1997 at the age of 58. Known as a "man of peace and justice," he was responsible for easing tensions during the Rodney King case, ensuring a peaceful march in 1978 during "The Longest Walk," a cross-country journey of American Indians, and for helping the U.S. Department of Justice establish a working relationship with Cesar Chavez and the United Farm Workers. 
THE HISTORY of Mexican American activism in Davenport is one of diminished isolation and increased visibility, from barrio to "iboicoteo!" [boycott]. It is rooted in the common experiences of second-generation Mexican Americans who became leaders and agents of change as they took up the national movement for La Causa and made it their own. The twin issues of labor rights and civil rights, inherent in the farm worker struggle for justice, struck a responsive chord among rank-and-file trade unionists who understood firsthand the principles of labor solidarity and grassroots collective action. Their support contributed to the momentum of the grape boycott movement in a part of the country where the UFWOC might not have expected to find significant support. As the boycott galvanized public attention on California grape pickers, it enabled local activists to draw attention to longstanding problems faced by Tejano migrant workers in Iowa as well as the state's permanent Spanishspeaking population. Working-class Chicanos from Davenport with a passion for social justice were instrumental in making the Delano grape fight a fight for the justice and dignity of all Mexican Americans. 